ISSN 2073-1558 online version: http://epub.oeaw.ac.at/eco.mont

\title{
Glaciological monitoring in Hohe Tavern National Park
}

\author{
Andrea Fischer, Martin Stocker-Waldhuber, Bernd Seiser, Bernhard Hynek \& Heinz Slupetzky
}

Keywords: glaciers, climate change, mass balance, glacier inventory

\section{Abstract}

Glaciers are important and fast changing landscape elements in Hohe Tavern National Park (HTNP). In 1998, 10\% of the HTNP area was covered with ice, less than half of the glaciated area during the Little Ice Age maximum. Glaciological monitoring includes mass balance measurements, glacier inventories, length change records and flow velocity measurements, complemented by climatological, hydrological and dendrochronological observations. All these data evidence the climate and glacier history of HTNP in an outstanding way, comparable to few other sites in the world.
Profile

Protected area

Hohe Tavern National Park

Mountain range

Alps

Country

Austria

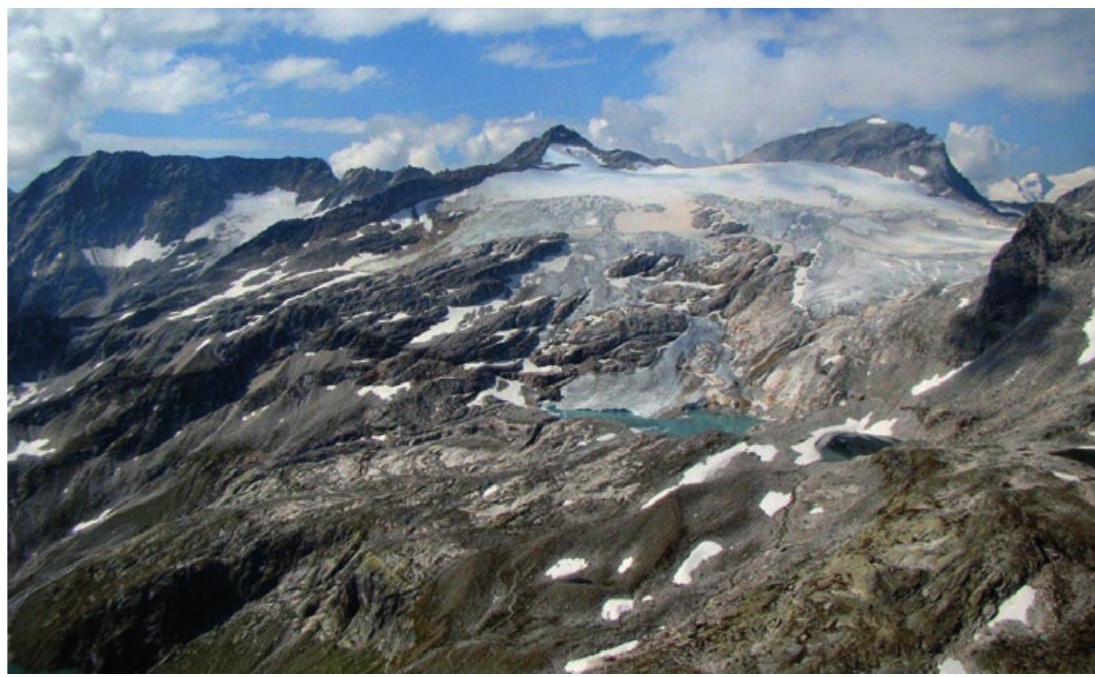

Figure 1 - Stubacher Sonnblick Kees (Granatspitz, range) on 7.9.2013. Below the fresh snow in the accumulation area, the underlying ochre Sabara dust from May 2013 is visible. In 2012 / 13 the glacier had a positive mass balance, which is very rare for recent years. (C) $H$. Slupetrky

$47^{\circ} 08^{\prime} \mathrm{N}$ ) was established in 1961 (Slupetzky 2004) near Stubacher Sonblick Kees $\left(12^{\circ} 35^{\prime} \mathrm{E}, 4^{\circ} 06^{\prime} \mathrm{N}\right)$ and Ödenwinkel Kees $\left(12^{\circ} 38^{\prime}\right.$ E, $\left.47^{\circ} 06^{\prime} \mathrm{N}\right)$.

The Austrian Alpine Club established a glacier survey in 1891 (Richter 1894). For several glaciers, like the Pasterzen Kees, much longer observations exist. Apart from length changes, elevation change has been measured from 1928 onwards by Paschinger (1969) and his successors. First ice flow velocity measurements date from 1882 by Seeland (1883).

These data have been complemented by proxy information on the Holocene, for example at the Pasterze forefield, since the first findings in 1990 (Slupetzky 1993). Rich dendrochronological evidence discovered since then allows a detailed interpretation of climate and glacier history for the Holocene (Patzelt 1973; Nicolussi \& Patzelt 2001). 


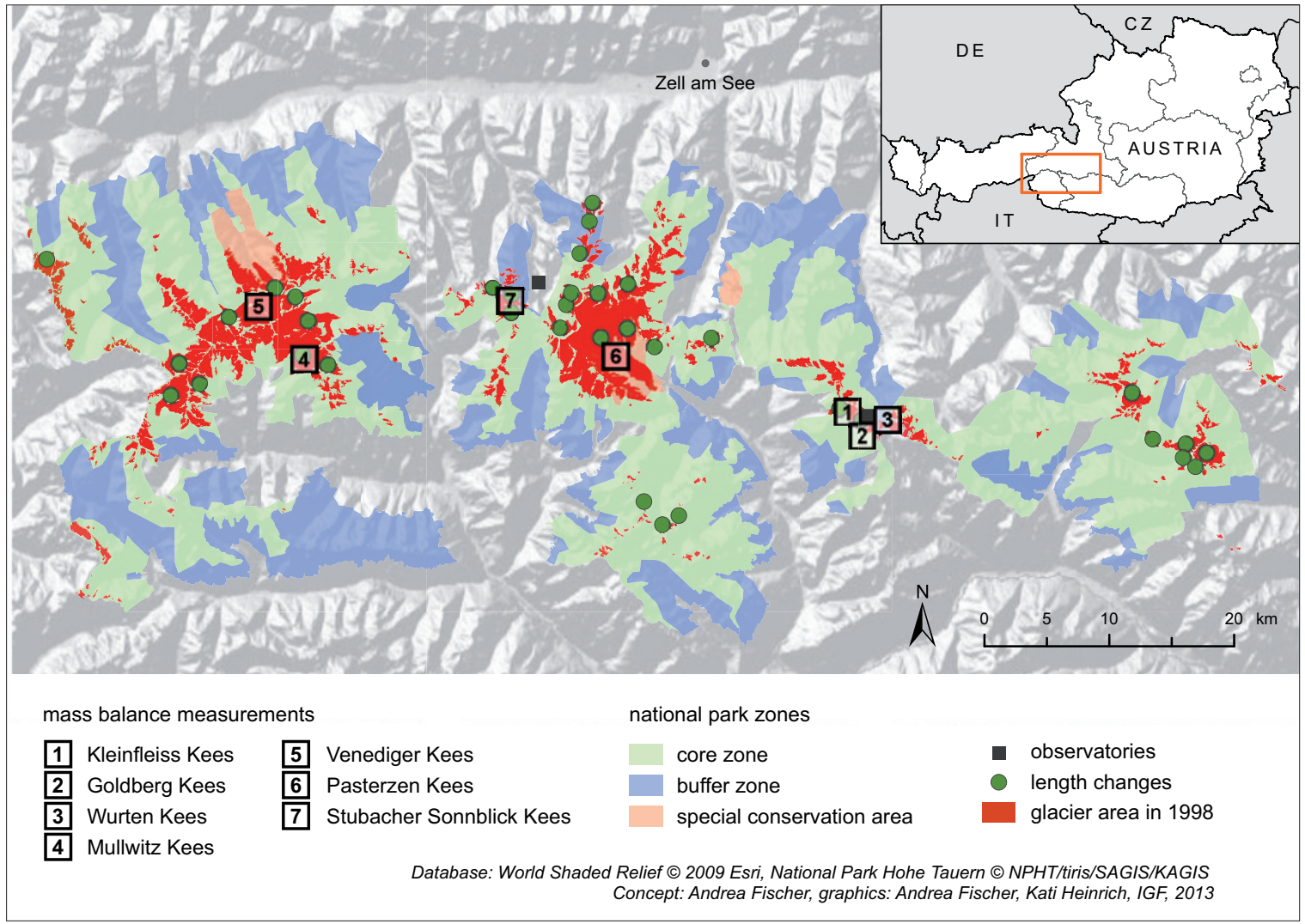

Figure 2 - Map of HTNP with location of specific glaciological measurement sites.

Today the glaciological long-term monitoring includes annual measurements of glacier mass balance at five glaciers, length changes at 36 glaciers and several ice flow velocity measurements at Pasterze, Hochalm Kees and Kälberspitz Kees. The observatory at Hoher Sonnblick and the weather station at Rudolfshütte, as well as runoff observations, e.g. at Obersulzbach Kees, complement the glaciological time series. Together with the three glacier inventories, these data allow numerical modelling of, for instance, glacier runoff. The studies have also resulted in several guidebooks for visitors of HTNP (e.g. Slupetzky \& Lieb 2013).

This report provides a glimpse of the rich glaciological data available for HTNP, collected by a number of different scientific institutions.

\section{Methods}

\section{Compilation of glacier inventories}

The first Austrian glacier inventory was based on airborne orthophotos dating from the year 1969 and contained glacier areas, surface elevations, as well as morphological and glaciological information of all Austrian glaciers (Patzelt 1980). Based on this material, Groß (1987) published area changes between the LIA maximum and 1969, using field mappings as well as orthophoto interpretation of moraine positions. The second Austrian glacier inventory was also based on orthophotos and mapped the glacier extent and surface elevation for the years 1997 to 1998 (Lambrecht
\& Kuhn 2007). The compilation of a third glacier inventory has been finished for the provinces of Salzburg (Stocker-Waldhuber et al. 2012) and Tyrol (Abermann et al. 2012), but not for Carinthia, as the third inventory is derived from LiDAR DEMs where these data were available.

\section{Measurement of length changes}

The monitoring of glacier length changes is done annually by members of the glacier survey of the Austrian Alpine Club following the instructions of Richter (1894). As the time series of glacier length changes in HTNP is one of the longest observed glaciological parameters anywhere, the method has been continued unchanged to avoid discontinuities. For measuring length changes, several fixed points, usually rocks, are marked in the glacier forefield. The distance from these fixed points to the glacier tongue is measured year by year in a specific direction as closely as possible to the ice flow line. The difference between these distances averaged for all fixed points close to a specific glacier tongue is the annual glacier length change. As glaciers do not retreat steadily, influenced not only by climatic, but also topographic and dynamic conditions, a larger sample of glaciers within a mountain range is usually surveyed to obtain representative averages.

\section{Measurement of glacier mass balance}

The mass change of a glacier can be calculated by comparing mass gain, in the form of snow, with mass loss by melt of snow and ice for a specific time period. 
Various indirect methods can be used, such as hydrological or geodetic methods, as well as the direct glaciological method, as used in the studies presented here, to determine the glacier mass balance (Paterson 1994).

The defined time period for the annual mass balance of the glaciers mentioned above is the hydrological year, which starts on October $1^{\text {st }}$. In addition, the year is divided into accumulation and ablation periods, when mass gain is expected during winter and mass loss during the summer months. Winter and summer mass balances are determined with the help of ablation stakes, snow depth soundings, snow pits and density measurements.

\section{Results}

\section{Glacier inventories}

The glacier inventories show a glacier retreat since the LIA maximum. In the glacier inventory of 1998, the 351 glaciers in HTNP covered a total area of $185.56 \mathrm{~km}^{2}$. In the glacier inventory of 1969 , the glaciated area was $207.25 \mathrm{~km}^{2}$. The ice cover thus decreased by $11 \%$ between 1969 and 1998, which is less than the $17 \%$ average for all Austrian glaciers. Although the third glacier inventory (2006) has not yet been fully completed for Carinthia, the average decrease of $8 \%$ for the glacier area in Tyrol (Abermann et al. 2012) may be taken as an indicator for glacier changes in this period. For the glacier decrease in Salzburg between 1998 and 2009, Stocker-Waldhuber et al. (2012) found a high variability in area changes for different regions, ranging from area losses of $15 \%$ in the Venediger Group to $-43 \%$ in the Ankogel Group.

\section{Time series of glacier length changes}

Observation of glacier oscillations, for example in the Glockner Group, were carried out as early as $1847-1849$ by the Schlagintweit brothers (Schlagintweit \& Schlagintweit 1850). Seeland took such measurements at Pasterzen Kees from 1879 until 1899. Richter, the initiator of the glacier survey of the Austrian Alpine Club, which has been operating since 1891, included Obersulzbach Kees and Karlinger Kees in his network. Today the length of 36 glaciers in HTNP is recorded annually (Patzelt 1970; Patzelt 1977; Fischer et al. 2013). The comparison of length changes recorded at Pasterzen Kees and Schlaten Kees shows that specific glaciers show individual reaction despite being exposed to fairly similar climatic conditions (Figure 3).

Time series of glacier mass balance Stubacher Sonnblick Kees and Ödenwinkel Kees Stubacher Sonnblick Kees and Ödenwinkel Kees are located close to the climate station Rudolfshütte in the Granatspitz Group. While the Stubacher Sonnblick Kees is a slope glacier, Ödenwinkel Kees is a valley glacier in a north-facing cirque with a debris covered tongue. Since 1963 / 64 glacier mass balance has been

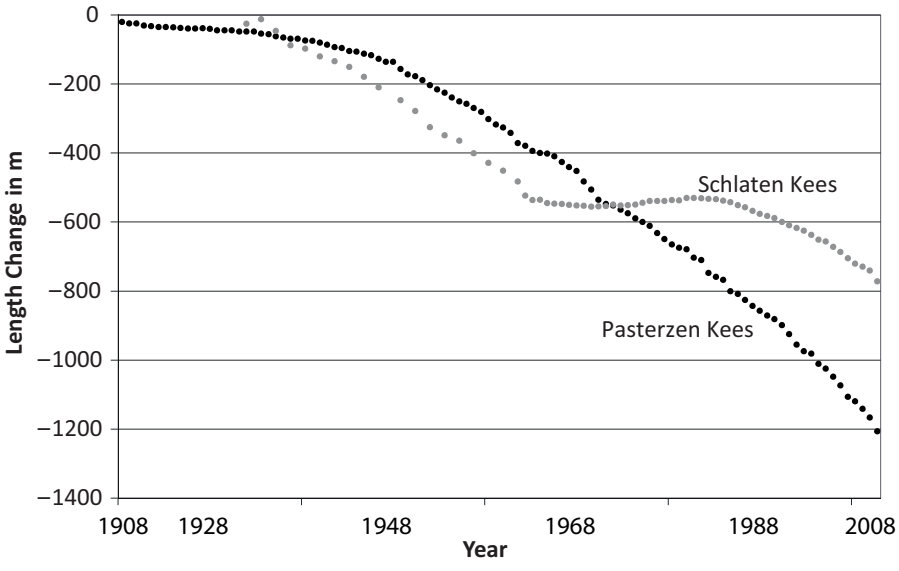

Figure 3 - Length changes of Pasterzen Kees and Schlaten Kees reveal a general retreat, but the faster reacting Schlaten Kees advanced during the 1980s / 1990s, whereas Pasterzen Kees retreated almost continuously.

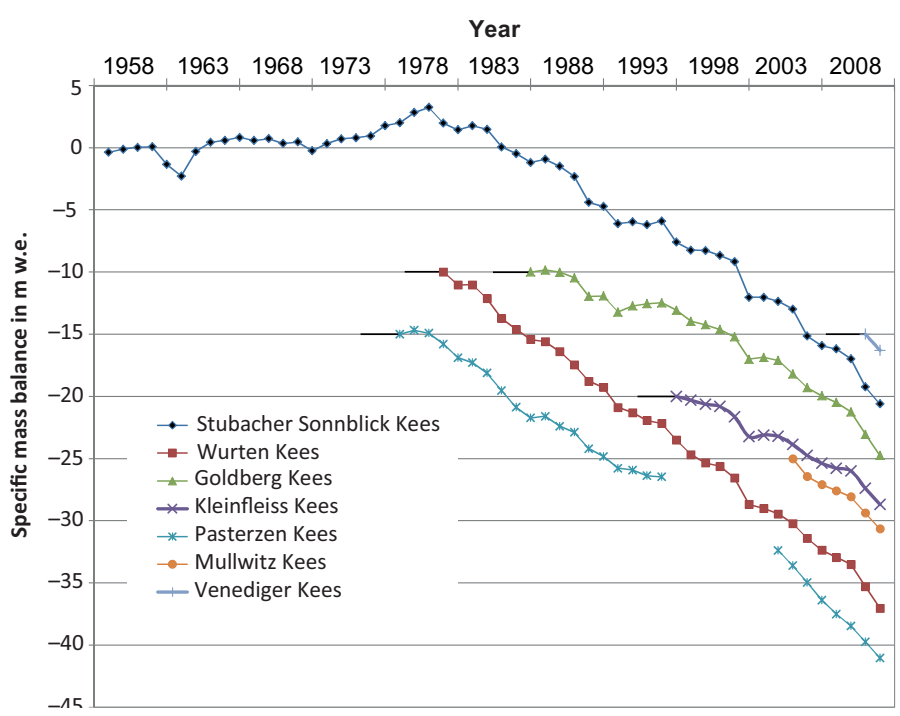

Figure 4 - Cumulated values of specific mass balances for the surveyed glaciers in HTNP. The graphs start arbitrarily at the $x$-axis (Pasterzen Kees: $-10 \mathrm{~m}$ ), although mass changes of course also happened before measurements began and during survey breaks. Starting points of the mass balance curves are marked with a thick line. Stubacher Sonnblick Kees has the longest time series, Pasterzen Kees the most significant mass loss during the last decade.

measured at Stubacher Sonnblick Kees by Slupetzky (1989), which makes it the first and longest mass balance series in HTNP. For the years 1959 to 1963, the mass balance has been reconstructed. On Ödenwinkel Kees, ice flow velocities have been recorded from 1962 onwards, using stone lines until 1965 and stakes thereafter (Slupetzky 1969). The specific mass balance of Stubacher Sonnblick Kees is the longest times series in the region (Figure 4).

\section{Kleinfleiss Kees, Wurten Kees, Goldberg Kees}

Wurten Kees (WUK, $13^{\circ} 00^{\prime} \mathrm{E}, 4^{\circ} 02^{\prime} \mathrm{N}$ ), Goldberg Kees (GOK) and Kleinfleiss Kees (FLK) are small glaciers in direct vicinity of the Sonnblick observatory at $3105 \mathrm{~m}$. (Figure 5). Measurements on WUK started in 1982, on GOK in 1986 and on FLK in 1999, and the direct measurements of mass balance are ac- 


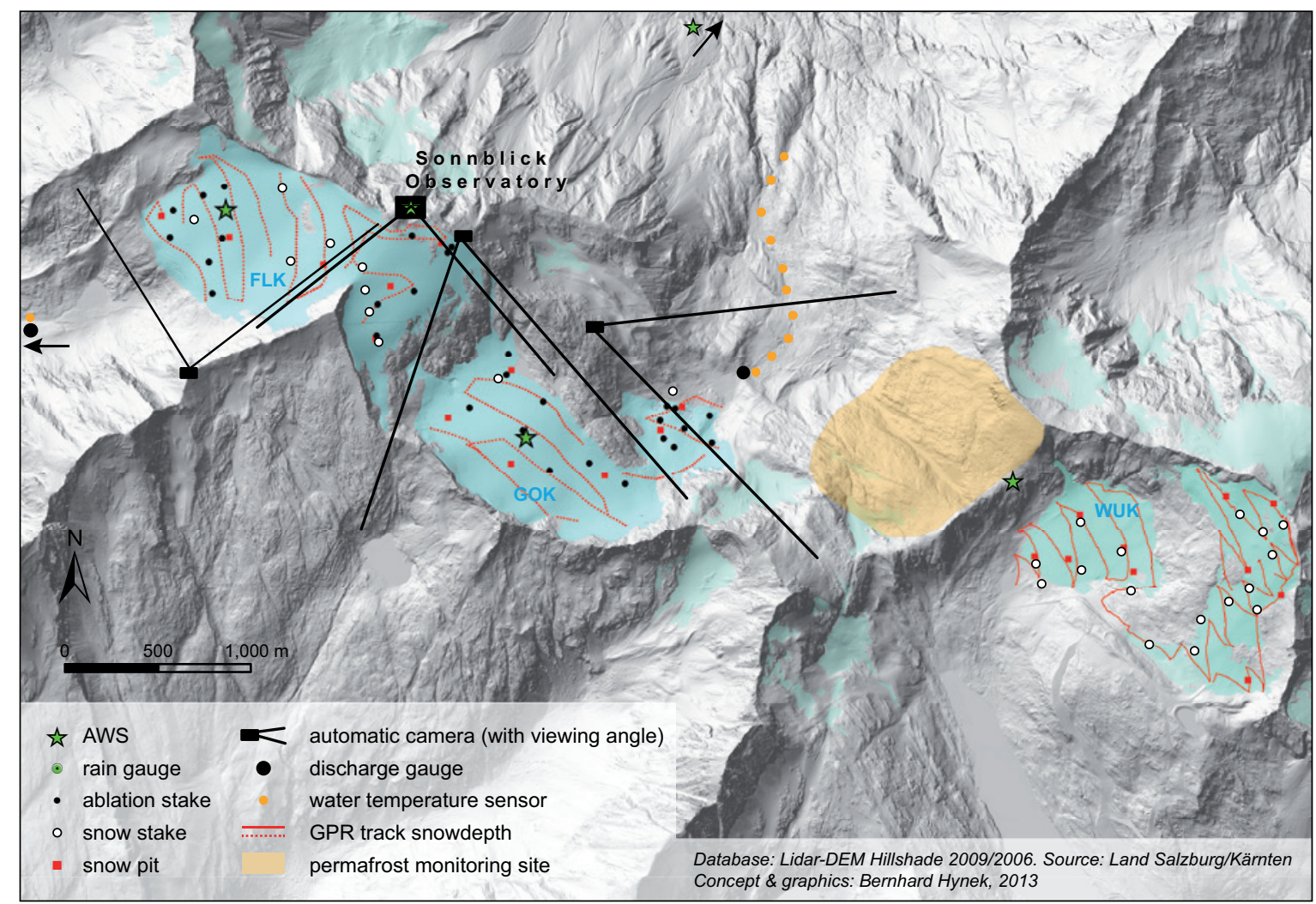

Figure 5 - Typical distribution of cryospheric measurement sites near the Sonnblick observatory, including mass balance glaciers Kleinfleiss Kees (FLK), Goldberg Kees (GOK) and Wurten Kees (WUK).

companied by dense monitoring of meteorological and glacio-hydrological parameters. Overall the mass balance of the three glaciers was negative in the last two decades, with an average mean ice thickness loss of about $0.8 \mathrm{~m} /$ year. The glacier areas are currently shrinking (2009: WUK $0.7 \mathrm{~km}^{2}$, FLK $0.8 \mathrm{~km}^{2}$, GOK $1.3 \mathrm{~km}^{2}$ ) and disintegrating. In 2010 Goldberg Kees broke up into three parts, while Wurten Kees consists of two separated glacier parts.

Mass balance measurement density is typically high, with up to 100 points $/ \mathrm{km}^{2}$ for winter balance and $10-20$ points $/ \mathrm{km}^{2}$ for annual balance. Since July 2011, two automatic weather stations are operating on FLK and GOK to measure the glacier surface energy budget. In addition to glacial runoff, monthly snow depth and water temperatures are measured in these two glacial catchments. In recent years the use of automatic cameras for snowline detection has enhanced measurement accuracy and facilitated the areal extrapolation of mass balance as well as glacio-hydrological model evaluation. While mass balance monitoring on Kleinfleiss Kees and Goldberg Kees is currently intensified by the use of automatic systems on the glaciers, monitoring on the upper Wurten Kees was stopped in 2012 because of the large anthropogenic influence from the Mölltaler Gletscher ski resort, which increasingly impaired the determination of a natural (i.e. climate induced) glacier mass change signal. Annual mass balance reports are published in the Sonnblickverein Jahresberichte and submitted to the World Glacier Monitoring Service (Böhm et al. 2007).

\section{Mullwitz Kees}

Mullwitz Kees is situated in the core zone of HTNP and can be divided into the inner Mullwitz Kees, also known as Rainer Kees, and the outer Mullwitz Kees, including the glacier tongue area known as Zettalunitz Kees. The mass balance measures were only conducted on the outer Mullwitz Kees (Figure 6). The glacier is mainly exposed to the south, has a great plateau without a surrounding mountain ridge. The accumulation area has therefore shifted to lower elevations zones as a result of wind drift. The highest point of the glacier is at an elevation of $3450 \mathrm{~m}$, the tongue reaches down to an elevation of $2900 \mathrm{~m}$ and in 2009 the glacier covered an area of about $3 \mathrm{~km}^{2}$ (StockerWaldhuber et al. 2013).

\section{Venediger Kees}

Venediger Kees $\left(47^{\circ} 12^{\prime} \mathrm{N}, 12^{\circ} 33^{\prime} \mathrm{E}\right)$ is located in the core zone of HTNP. The original name of this glacier system was Obersulzbach Kees. Due to area loss since 1850, the connection between individual parts of Obersulzbach Kees was lost and the resulting individual glaciers were renamed. In 2009 Venediger Kees covered an area of about $2.17 \mathrm{~km}^{2}$. The glacier extends up to an altitude of $3400 \mathrm{~m}$, just below the Großvenediger summit, the lowest part of the glacier tongue reached down to $2480 \mathrm{~m}$ in 2009. The Venediger Kees is a typical valley glacier. Such glaciers are constrained by underlying topography and gravity, with an accumulation area in a firn basin and an ablation area mostly congruent with the glacier tongue. 


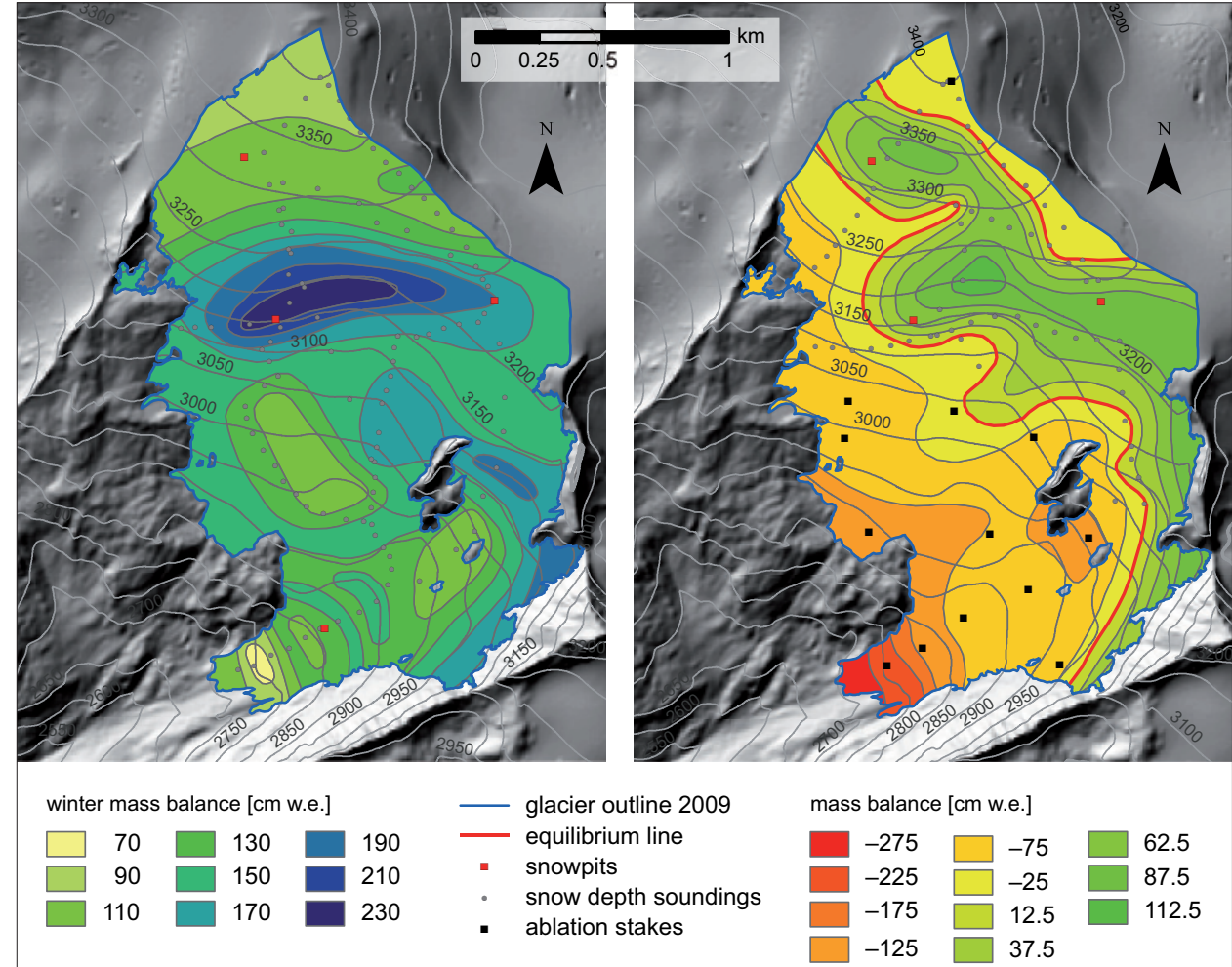

Database: Austrian Glacier Inventory, Concept \& graphics: Martin Stocker-Waldhuber, 2013
Figure 6 - Observation network and mass balance map of Mullwitr Kees for the year 2013.
Glacier monitoring was launched in May 2012 as a supplement to the runoff gauge maintained by the Hydrographic Office of the Land Salzburg at an altitude of $2202 \mathrm{~m}$, in front of a peri-glacial lake. The monitoring programme includes direct mass balance measurements and three time lapse cameras for recording changes in the snow cover.

For measuring the ablation, 13 ablation stakes were installed at the beginning of monitoring, 11 on Venediger Kees and 2 on Sulzbacher Kees (see Figure 7). Two further ablation stakes were installed on Sulzbacher Kees to secure the measurement series. Accumulation is measured in three snow pits and a number of snow depth probings.

\section{Pasterzen Kees}

In 2004 the Central Institute of Meteorology and Geodynamics (ZAMG) restarted measuring the annual mass balance on Pasterzen Kees, Austria's biggest glacier, which had been monitored by hydropower generator Tauernkraft AG from 1980 to 1997. To extract the typical mass balance distribution on the glacier, a very dense network of point measurements (Figure 8) with more than 60 stakes has been established in the ablation area as well as accumulation measurements with snow pits, snow probings and snow depth measurements by ground penetrating radar (GPR).

Alongside glacier mass balance observations, various other measurements are carried out on Pasterzen

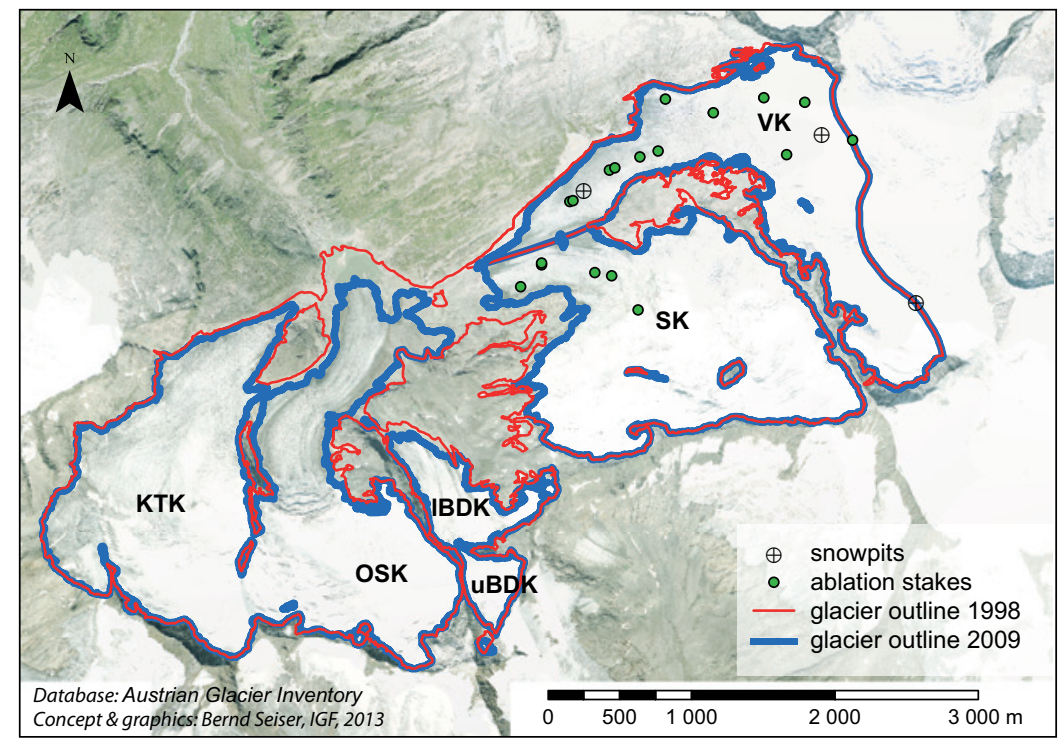

Figure 7 - Overview of the catchment of Venediger Kees (VK), Sulzbacher Kees (SK), lower Bleidächer Kees (IBDK), upper Bleidächer Kees (uBDK), Obersulzbach Kees (OSK) and Krimmlertörl Kees (KTK) with measuring points. 


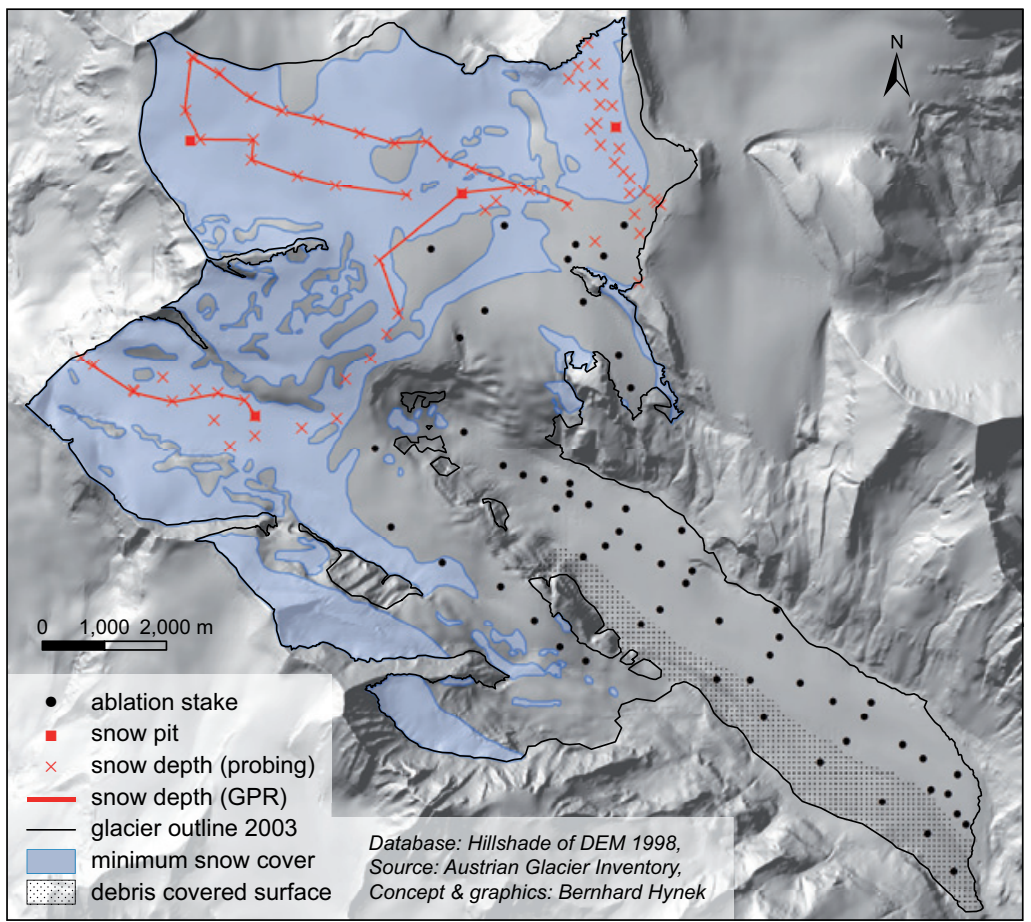

Figure 8 - Mass balance monitoring network on Pasterzen Kees glacier 2006 / 2007.

Kees: ice thickness measurements with GPR and reflection seismic, ice surface velocity measurements by GPS stations and meteorological measurements on automatic weather stations on the glacier. Monitoring will be continued in the coming years and further enhanced by the use of automatic cameras and automatic surface melt sensors.

Historical maps and documents: Case study Mullwitz Kees

Mullwitz Kees has been subject to several investigations since the mid-19 $9^{\text {th }}$ century, when the glaciers around the Großvenediger (3664 $\mathrm{m}$ ) were described for the first time (Kürsinger \& Spitaler 1843). The first detailed map of Mullwitz Kees was created as early as 1866 (Keil 1866). The extent of the glaciated area on Mullwitz Kees has been recorded since the end of the LIA around 1850 by means of moraine mapping and in the years 1930, 1969, 1998 and 2009 (Figure 9, Table 1; Stocker-Waldhuber 2010).

\section{Discussion and conclusions}

Glacier monitoring in HTNP has a long history and tradition. As one of the few areas in the world where earliest glacier maps date back to the early $17^{\text {th }}$ century and a wealth of dendrochronological evidence exists, the Hohe Tauern area has great potential for detailed studies on the Holocene and LIA climate history. These data are supplemented by excellent climate data from high elevation observatories. The ongoing mass balance programmes are geographically well distributed and provide a good data basis for numerical modelling. For the next decade these programmes should not only be kept in operation but more closely linked with ongoing ecological research. Moreover, the high visibility of glacier changes in the landscape can be put to good use for impressing on visitors of HTNP the variability of landscape changes within the Holocene, especially the rapid changes in recent times. Increasing efforts to visualize glacier changes from historical sources could be another attractive educational feature of HTNP.

\section{Acknowledgements}

The glaciological observations are supported by Hohe Tauern National Park, the hydrological services of the federal governments of Tyrol, Salzburg and Carinthia, by the Austrian Alpine Club, by the Federal Ministry of Life, Austria and the Austrian Hydro Power AG. The authors wish to thank Kati Heinrich for fine-tuning and improving the maps used in this article.

Table 1 - Area change of Mullwitr. Kees between 1850 and 2009.

\begin{tabular}{|l|r|r|r|r|r|}
\hline year & 1850 & 1930 & 1969 & 1998 & $\mathbf{2 0 0 9}$ \\
\hline area $\left[\mathbf{k m}^{2}\right]$ & 5.49 & 4.52 & 3.52 & 3.24 & 3.03 \\
\hline$\%$ of the area 1850 & 100 & 82 & 64 & 59 & 55 \\
\hline period 1850-1930 & $1930-1969$ & $1969-1998$ & $1998-2009$ & $1850-2009$ & \\
\hline area change $\left[\mathbf{k m}^{2}\right]$ & -0.97 & -1.00 & 0.28 & -0.22 & -2.47 \\
\hline
\end{tabular}




\section{References}

Abermann, J. B. Seiser, I. Meran, M. Stocker-Waldhuber, M. Goller \& A. Fischer 2012. A new ALS glacier inventory of North Tyrol, Austria, for 2006 AD. Zeitschrift für Gletscherkunde und Glazialgeologie 43/44: 109-119.

Fischer, A., G. Patzelt, H. Kinzl 2013. Length changes of Austrian glaciers 1970-2011. http://doi. pangaea.de/10.1594/PANGAEA.821823

Gross, G. 1987. Der Flächenverlust der Gletscher in Österreich 1850-1920-1969. Zeitschrift für Gletscherkunde und Glazialgeologie 23 (2): 131-141.

Keil, F. 1866. Ein Beitrag zur Kenntnis der Venedigergruppe. Jahrbuch des österreichischen Alpenvereins 2: 99-113.

Kürsinger, I.v. \& F. Spitaler 1843. Der Groß-Venediger in der norischen Centra-Alpenkette, seine erste Besteigung 3. Sept. 1841 und sein Gletscher in seiner gegenwärtigen und ehemaligen Ausdehnung.

Lambrecht, A. \& M. Kuhn 2007. Glacier changes in the Austrian Alps during the last three decades, derived from the new Austrian glacier inventory. Annals of Glaciology 46 (1): 177-184. doi:10.3189/172756407782871341

Lieb, G.K. \& H. Slupetzky 2011. Die Pasterze. Der Gletscher am Großglockner 2011. Salzburg.

Lieb, G.K. \& H. Slupetzky 2004. Gletscherweg Pasterze (Glocknergruppe). $\ddot{O} A V$-Reihe: Naturkundliche Fübrer zum Nationalpark Hohe Tauern 2.

Nicolussi, K. \& G. Patzelt 2001. Untersuchungen zur holozänen Gletscherentwicklung von Pasterze und Gepatschferner (Ostalpen). Zeitschrift für Gletscherkunde und Glarialgeologie 36: 1-87.

Paschinger, H. 1969. Die Pasterze in den Jahren 1924 bis 1968. Neue Forschungen im Umkreis der Glocknergruppe. Wissenschaftliche Alpenvereinshefte 21: 201-217.

Paterson, W. 1994. The physics of Glaciers.

Patzelt, G. 1970. Die Längenmessungen an den Gletschern der österreichischen Ostalpen 1890-1969. Zeitschrift für Gletscherkunde und Glazialgeologie 6 (1-2): 151-159.

Patzelt, G. 1977. Statistik der Längenmessungen an den österreichischen Gletschern 1960 bis 1975. Zeitschrift für Gletscherkunde und Glazialgeologie 12 (1): 91-94.

Patzelt, G. 1980. The Austrian Glacier inventory: Status and first results. LAHS Publication, 126: 181-183. hdl:10013/epic.40976.d001

Patzelt, G. 1973. Die Neuzeitlichen Gletscherschwankungen in der Venedigergruppe (Hohe Tauern, Ostalpen). Zeitschrift für Gletscherkunde und Glazialgeologie 9 (1-2): 5-57.

Böhm, R., W. Schöner, I. Auer, B. Hynek, C. Kroisleitner \& G. Weyss 2007. Gletscher im Klimawandel. Vom Eis der Polargebiete zum Goldbergkees in den Hohen Tauern.

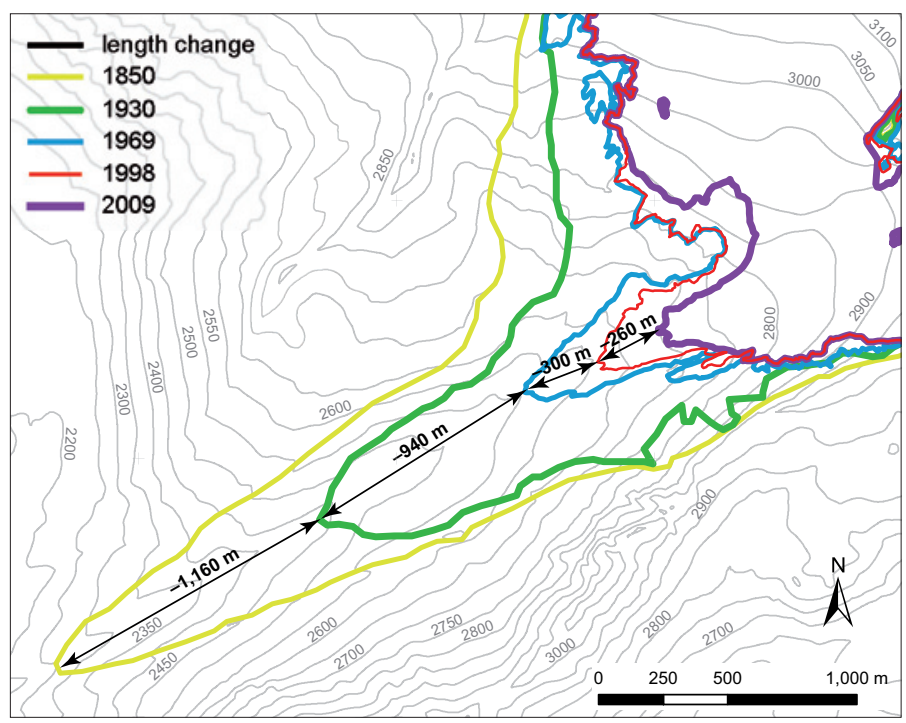

Figure 9 - Area change of the tongue of Mullwitz Kees between 1850 and 2009.

Richter, E. 1894. Die wissenschaftliche Erforschung der Ostalpen seit der Gründung des Österreichischen und Deutschen Alpenvereins. Zeitschrift des Deutschen und Österreichischen Alpenvereins 25: 1-94.

Schlagintweit, H. \& A. Schlagintweit 1850. Untersuchungen über die physikalische Geographie der Alpen in ibren Beziehungen zu den Phänomenen der Gletscher, zur Geologie, Meteorologie und Pflanzengeographie. Leipzig.

Seeland, F. 1883. Studien am Pasterzengletscher IV. Zeitschrift des Deutschen und Österreichischen Alpenvereins 14: 93-97.

Slupetzky, H. 1969. Ergebnisse der Geschwindigkeitsmessungen am Ödenwinkelkees (westl. Glocknergruppe, Stubachtal, Hohe Tauern) in den Jahren 1962-1968. In: DAV (Hrsg.), Neue Forschungen im Umkreis der Glocknergruppe 21: 219-228.

Slupetzky, H. 1993: Holzfunde aus dem Vorfeld der Pasterze. Erste Ergebnisse von 14 C Datierungen. Zeitschrift für Gletscherkunde und Glazialgeologie 26: 179-187.

Slupetzky, H. 1989. Die Massenbilanzreihe vom Stubacher Sonnblickkees 1958/59 bis 1987/88. Die Berechnung der Massenbilanz 1980/81 bis 1987/88 (und 1958/59 bis 1962/63). Zeitschrift für Gletscherkunde und Glarialgeologie 25 (1): 69-89.

Slupetzky, H. 2004. Die Rudolfshütte $(2304 \mathrm{~m})$ in den Hohen Tauern - die zweithöchste ganzjährig besetzte Synopstation in Österreich. Festschrift 100. Jahresbericht des Sonnblickvereins. Wien: 48-51

Slupetzky, H. \& G.K. Lieb 2013. Gletscherweg Obersulzbachtal. Naturkundlicher Führer zum Nationalpark Hohe Tauern. Austrian Alpine Club, Innsbruck.

Stocker-Waldhuber M., H. Wiesenegger, J. Abermann, B. Hynek \& A. Fischer 2012. A new glacier inventory of the province of Salzburg, Austria 2007/2009. Zeitschrift für Gletscherkunde und Glazialgeologie 43/44: 121-128. 
Stocker-Waldhuber, M. 2010. Untersuchung des Massenhaushalts am Mullwitzkees, im NP Hohe Tauern. Master's thesis, Institute for Meteorology and Geophysics, University of Innsbruck, Austria

Stocker-Waldhuber, M., A. Fischer \& M. Kuhn 2013. Glacier Mass Balance of Mullwitzkees, Hohe Tauern, Austria, from 2006-2012. http://doi.pangaea. de/10.1594/PANGAEA.806662

\section{Authors}

\section{Andrea Fischer}

is coordinator of the glaciological survey of the Austrian Alpine Club and national correspondent of the World Glacier Monitoring Service. She works as a scientist at the Institute for Interdisciplinary Mountain Research at the Austrian Academy of Sciences (ÖAW). Contact: andrea.fischer@oeaw.ac.at

\section{Bernhard Hynek}

is scientist at the Department of Climate Research at the Zentralanstalt für Meteorologie und Geodynamik (ZAMG) in Vienna. He is involved in the mass balance monitoring programmes of ZAMG on Goldberg Kees, Kleinfleiss Kees, Wurten Kees and Pasterzen Kees. Zentralanstalt für Meteorologie und Geo- dynamik, Abteilung Klimaforschung, Hohe Warte 38, 1190 Wien. Contact: bernhard.hynek@zamg.ac.at

\section{Bernd Seiser}

is scientist at the Institute for Interdisciplinary Mountain Research at the Austrian Academy of Sciences (ÖAW) and carries out the mass balance measurements at Venediger Kees. Contact: bernd.seiser@oeaw.ac.at

Martin Stocker-Waldhuber

is scientist at the Institute for Interdisciplinary Mountain Research at the Austrian Academy of Sciences (ÖAW) and carries out the mass balance measurements at Mullwitz Kees. Contact: stocker-waldhuber@oeaw.ac.at

\section{Heinz Slupetzky}

emeritus professor of geography at the University of Salzburg. Has carried our research in HTNP for many decades and in the 1960s founded mass balance monitoring at Stubacher Sonnblick Kees (Hohe Tauern range) on behalf of the Hydrological Service of Salzburg. Dept. of Geography and Geology, University of Salzburg, Austria. Hellbrunnerstraße 34, 5020 Salzburg. Contact: heinz.slupetzky@sbg.ac.at 